\title{
THE CONSTRUCTION CLIENT SATISFACTION MODEL: A PLS-SEM APPROACH
}

\author{
Serdar DURDYEV ${ }^{*}$, Ali IHTIYAR ${ }^{2}$, Audrius BANAITIS ${ }^{3}$, Derek THURNELL ${ }^{1}$ \\ ${ }^{1}$ Department of Engineering and Architectural Studies, Ara Institute of Canterbury, Christchurch, \\ New Zealand \\ ${ }^{2}$ Department of Business Administration, Zaman University, Phnom Penh, Cambodia \\ ${ }^{3}$ Department of Construction Management and Real Estate, Vilnius Gediminas Technical University, \\ 10223 Vilnius, Lithuania
}

Received 30 October 2017; accepted 03 January 2018

\begin{abstract}
The satisfaction of the client is of utmost importance in procuring future projects; however, anecdotally client satisfaction (CS) is not adequately considered in many developing countries. Factors associated with the influence of service quality (SQ) on construction client satisfaction and how it affects their behavioural intentions in Cambodia are investigated. A theoretical structural model was developed to investigate the influence of five SQ factors on CS and their links to the future behavioural intentions of the client. A partial least square approach of the structural equation modelling technique (PLS-SEM) was employed to analyse data collected from a questionnaire survey of 227 participants comprising the clients of small and medium size projects. The structural model adapts 22 attributes across five SQ factors, namely: reliability; responsiveness; assurance; empathy, and tangible factors. PLS-SEM outcomes confirmed that the future behavioural intentions of the client are influenced by their satisfaction over the service excellence provided by construction companies. Moreover, treating every client individually and demonstrating an approachable attitude towards their needs will increase their satisfaction with the experience they had with a contractor. Findings and recommendations of the study may be useful to construction companies who are seeking ways to improve CS in developing countries.
\end{abstract}

Keywords: client satisfaction, service quality, PLS-SEM, construction, Cambodia.

\section{Introduction}

Having an annual contribution of $9-10 \%$ to the country's Gross Domestic Product (GDP) makes the construction and real estate industry the second most important driver of Cambodian economic growth (MEF 2016). For instance, residential project approvals have accelerated to reach US $\$ 8.5$ billion in 2016, compared with US $\$ 3.3$ billion in 2015 (Durdyev, Mbachu 2017). It seems that investors' (especially overseas) appetite remains strong, which has made the construction industry in Cambodia an industry in transition, mainly in the last decade. Domestic construction companies are facing stiff competition as the market has been attracting global players, the vast majority of whom are from China, Singapore, South Korea, Thailand, Indonesia and Malaysia (Yonn 2017). In order to survive in this competitive business environment, substantial research efforts in the construction industry context of Cambodia are underway, which include automation for construction activities, prefabrication and application of building information modelling for efficient design and management of projects. The significance of these areas cannot be understated as each of them represents a facet of the construction business, which requires proper attention (Lessing et al. 2017).

Having a variety of investors from different countries - from the investor's perspective - shows the potential of the sector, as well as its level of competitiveness. Therefore, construction companies develop different strategies (as do investors) to win construction project bids and those who are currently operating try to keep client satisfaction at the highest level to procure future projects in the country (Durdyev et al. 2013). Thus, client satisfaction in the Cambodian construction industry is of strategic importance, as the most effective way of marketing in the country is through word of mouth.

*Corresponding author. E-mail: durdyevs@ara.ac.nz 
Obtaining new work and ensuring project delivery on schedule, within budget, and meeting quality standards are just a few of the many services of a construction company (Durdyev, Ismail 2016). Operations and maintenance, training in complex building systems, financial engineering and facility management are some of the services required of construction companies. Along with the project cost, schedule and quality, construction client satisfaction is one of the significant elements measuring the success of any contractor in the construction industry (Othman 2015). Even though it is mostly applied in other industries, the adoption of the service quality and client satisfaction approach for companies offering design and build services is vital for better differentiation between competitors (Preece, Tarawneh 1997). What differentiates leading construction companies from others is service excellence, which improves productivity, maintains client loyalty, and creates positive word-of-mouth advertising, all of which can create advantages in the competitive business environment. Due to its significance, client satisfaction has received broad attention in the literature (Barret 2000; Torbica, Stroh 2001; Maloney 2002; Yasamis et al. 2002; Yang, Peng 2008; Kärnä et al. 2009; Li et al. 2013; Hsu, Juan 2016; Aliakbarlou et al. 2017; Hadidi et al. 2017). For example, construction client satisfaction was perceived to be the most significant determinant of success in the Turkish construction industry context (Arslan, Kivrak 2009). In another study, Foster and Ganguly (2013) measured clients' satisfaction though the identification of gaps between their expectations and satisfaction of those expectations, where they mainly focused on the following five dimensions of service quality: 1) tangibles; 2) reliability; 3 ) responsiveness; 4) assurance, and 5) empathy. However, Forsythe (2015) gave priority to two of the aforementioned dimensions, which are reliability and tangibles. It is recommended that construction companies should formulate the satisfaction criteria for each project and client, rather than trying to produce a standardized list of quality criteria, which is not possible (Maloney 2002). Thus, studies from other countries and projects may not be entirely applicable in the Cambodian construction industry, as perceived service quality and client satisfaction are industry specific, due to the differences in the socio-cultural, legislative and regulatory environments within which construction operations are undertaken. Moreover, no notable research or industry initiatives had been undertaken in Cambodia until the commencement of this scoping study. Therefore, using the structural equation modelling (SEM) method, this study aims to investigate the influence of contractors' service quality on construction client satisfaction in the Cambodian construction industry. To achieve this aim, this study was undertaken with the following objectives:

- to identify the service quality components of the construction industry context;

- to develop a structural equation model (SEM) and use it to quantify the relationships between service quality and client satisfaction in the Cambodian construction industry.
The remainder of this paper is structured as follows. The next section presents a review of the literature on service quality and client satisfaction in the construction context. In the second section, the theoretical framework of study is presented. In the third section, the techniques applied (i.e., SERVQUAL and Partial Least Square Structural Equation Modelling) are presented. Section four describes the results. The last section discusses the framework's implications for research and industry, limitations, its practical validation, as well as offers concluding remarks.

\section{Literature review}

Quality has become such a buzzword for the improvement of any business for a long time and therefore, one of the most frequently researched topics (Womack et al. 2008; Forsythe 2015; Ferreira et al. 2017; Osei-Kyei et al. 2017). From the service industry perspective, receiving more attention (quality of service) increases customers' satisfaction, subsequently strengthening bonds (loyalty) between them and a company (Nadiri, Gunay 2013), which may lead to them recommending that company to others $(\mathrm{Wu}$, Liang 2009), which ultimately will reflect on profitability. Service quality has also been regarded as a true reflection of the manufacturing/production success of any business, as investing more resources and efforts towards increasing the quality of a product yields increased annual income (Fajgelbaum et al. 2011). Emphasising the significance of customer satisfaction, Kotler and Armstrong (2013) describe business success as a factor in achieving client satisfaction, which contributes to expansion of market share, thereby increasing profits via repeat sales, and enhancing long-term customer ethical standards (i.e. equity). Furthermore, Oliver and Linda (1981) asserted that improvement in client satisfaction is a key to survival in a competitive business environment.

Customers' perceptions towards their choice of, and level of satisfaction with, the product will eventually have a positive influence on their future intentions (Ihtiyar, Ahmad 2014). However, in recent years, quality perception has shifted from a merely product-centric to client-centric quality, which is also referred to as a client satisfaction (Sheth et al. 2011). For instance, Vargo and Lusch (2004) proposed a logic whereby products are a simple service delivery vehicle to achieve client-specific needs at the highest level of expectation. Thus, customers' perceived value of quality depends on the level of service provided; instead of the quality level of product they purchase (Vandermerwe 1994).

Service quality based on customer perception has received broad attention by researchers in the construction management context (Lee, Yu 2012), even though it has been traditionally associated with service industries, within which construction is not usually grouped. Hadidi et al. (2017) undertook a study focusing on the design services for large scale projects and recommended implementation of quality management systems (QMS) for better construction clients' satisfaction. However, rather than 
simply implementing costly QMSs, they further stressed the validation of systems' effectiveness. Furthermore, from the contractor's perspective, Zulu and Chileshe (2010) investigated the level of service quality required of building maintenance contractors in Zambia and further stressed the importance of responsiveness of contractors towards the construction clients' needs.

Mainly from construction clients' perspectives, Sunindijo et al. (2014) established relationships between four dimensions of service quality. Using structural equation modelling, reliability, responsiveness and assurance were found to be significantly influencing dimensions, while tangibles (such as documentation quality, and quality of the workforce) was less influential on construction client satisfaction. Consequently, contractors were further recommended to address - after project completion - the factors both negatively and positively affecting construction client satisfaction as lessons learned for future projects. By focusing on construction clients' perceptions of a specific market setting, Forsythe (2016) developed a conceptual approach to understand the dynamic influence of service quality on client satisfaction, as well as identifying contextual variables that have an influence on the relationships within the residential construction industry in the UK.

Notwithstanding the extensive extant literature concerning the elements of service quality and client satisfaction in the construction context, daily dynamic changes in the construction operation services have yet to receive much attention. Moreover, due to cultural context of Cambodian construction industry, there are parameters influencing service quality and client satisfaction. For instance, lack of skilled workforce (Durdyev et al. 2017a), frequent project delays (Durdyev et al. 2017b) and lack of quality standards are the most critical factors affecting the level of satisfaction. Therefore, authors have included the following factors (ASU2, ASU3, RLB2, RLB4, EMP2, TNG2), which thought to be significant due to cultural context of the industry in Cambodia. Table 1 depicts service quality components within the construction industry context with a robust backing in the literature, which therefore provides a basis for achievement of the first objective of the study. Furthermore, regardless of the similarities between projects, every one of them (due to their uniqueness) and every client should be treated separately. Thus, instead of merely focusing on several indicators of dissatisfaction, the focus of this study is to examine the influence of service quality constructs on construction client satisfaction, and its total impact on behavioural intention in the Cambodian construction industry context. Due to its unique features, structural equation modelling, as a robust analysis technique (Byrne 2009), was used to estimate a quantitative inter-dependent relationship between independent variables in this study (Durdyev et al. 2017c).

\section{Theoretical framework}

Review of the relevant literature (refer to Table 1) on the subject suggests various components of service quality (SQ) that affect client satisfaction (CS) in the construction industry context. These components can be grouped into five general categories: reliability (RLB); responsiveness (RES); assurance (ASU); empathy (EMP), and tangibles (TNG). Furthermore, behaviour intention (BI) has a positive influence on customer satisfaction. Hence,

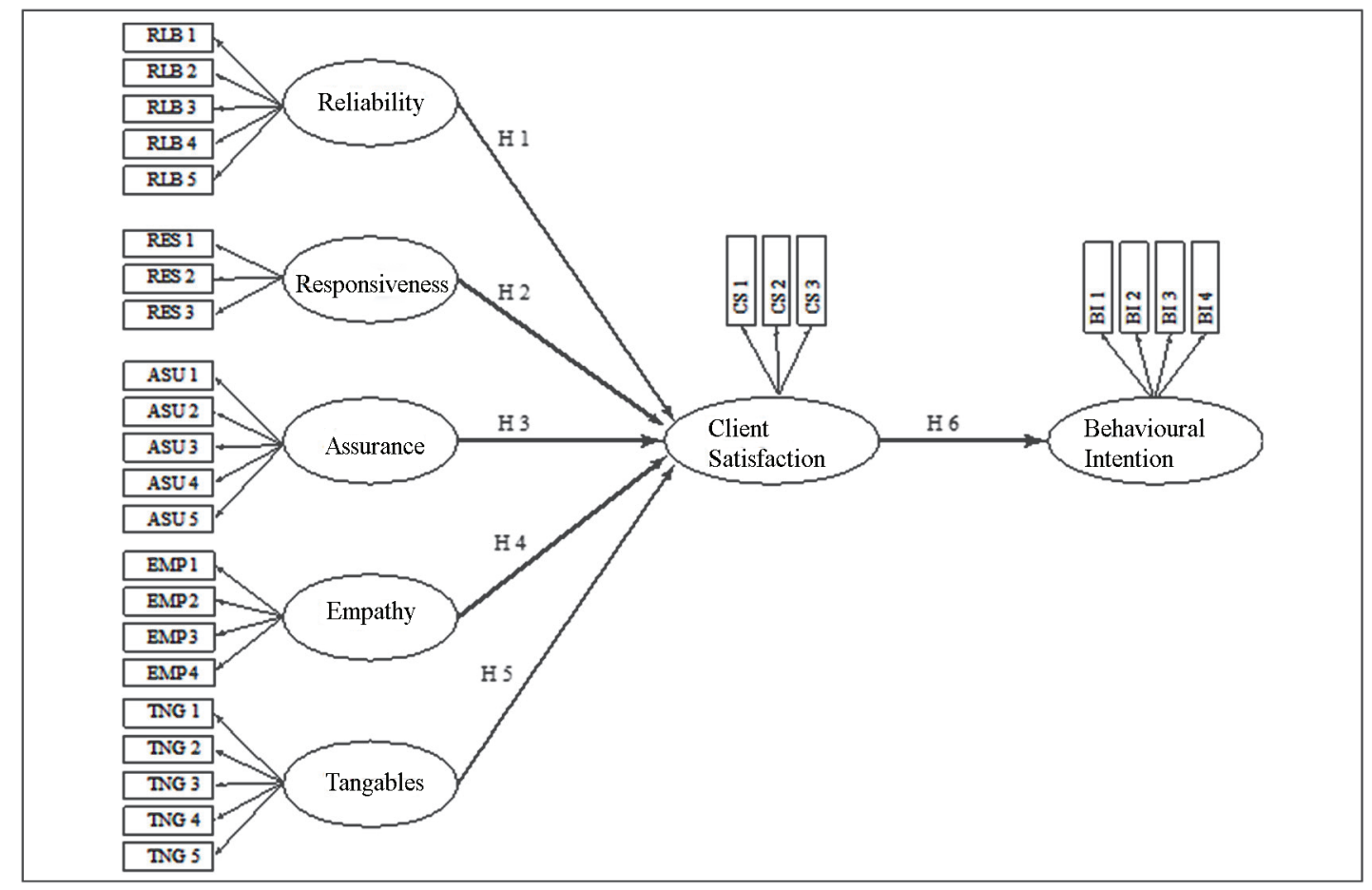

Figure 1. Research framework of the study 
Table 1. Items used for questionnaire design

\begin{tabular}{|c|c|c|}
\hline \multirow{2}{*}{ Item code } & Item & \multirow{2}{*}{ Reference } \\
\hline & Reliability & \\
\hline RLB1 & Provision of services as promised & Kang and James (2004) \\
\hline RLB2 & Display a helpful attitude in solving problems & Ahmed and Kangari (1995) \\
\hline RLB3 & Work order performed as it is required & Sunindijo et al. (2014) \\
\hline RLB4 & Provision of services at the promised time & Abdullah et al. (2014) \\
\hline \multirow[t]{2}{*}{ RLB5 } & Report periodic/continuous work progress & Ahmed and Kangari (1995) \\
\hline & Responsiveness & \\
\hline RES1 & Keeping clients informed of the time when the service will be performed & Sunindijo et al. (2014) \\
\hline RES2 & Providing immediate service to clients & Eager et al. (2001) \\
\hline \multirow[t]{2}{*}{ RES3 } & Willing to help clients & Kang and James (2004) \\
\hline & Assurance & \\
\hline ASU1 & Employees who instil confidence in clients & Kang and James (2004) \\
\hline ASU2 & Assuring the quality of work is up to standard & Durdyev et al. (2014) \\
\hline ASU3 & Displaying courtesy consistently & Ahmed and Kangari (1995) \\
\hline ASU4 & Having sufficient knowledge to answer client's questions & Sunindijo et al. (2014) \\
\hline \multirow[t]{2}{*}{ ASU5 } & Being competent in problem solving & Sunindijo et al. (2014) \\
\hline & Empathy & \\
\hline EMP1 & Understanding client-specific needs & Kang and James (2004) \\
\hline EMP2 & Offer personalized attention to clients & Vera and Trujillo (2013) \\
\hline EMP3 & Post-project maintenance service & Sunindijo et al. (2014) \\
\hline \multirow[t]{2}{*}{ EMP4 } & Business hours convenient for client & Kang and James (2004) \\
\hline & Tangibles & \\
\hline TNG1 & Sufficient number of latest tools and equipment in good condition & Kang and James (2004) \\
\hline TNG2 & Sufficient workforce to complete a project & Durdyev and Mbachu (2011) \\
\hline TNG3 & Sufficient storing facility and good housekeeping & Sunindijo et al. (2014) \\
\hline TNG4 & Proper dress code for workforce complying with code of conduct & Kang and James (2004) \\
\hline \multirow[t]{2}{*}{ TNG5 } & Detailed documentation & Ahmed and Kangari (1995) \\
\hline & Construction client satisfaction & \\
\hline CS1 & I am satisfied with the service provided by the contractor & Kang and James (2004) \\
\hline CS2 & I am satisfied that I chose this contractor wisely & Kang and James (2004) \\
\hline \multirow[t]{2}{*}{ CS3 } & I had a great experience using this contractor & Kang and James (2004) \\
\hline & Behavioural intention & \\
\hline BI1 & Will you be recommending this contractor to other people in the future? & Sunindijo et al. (2014) \\
\hline BI2 & If you have the opportunity to use the same contractor in future, would you? & Sunindijo et al. (2014) \\
\hline BI3 & Will you be waiting for the same contractor in case of unavailability? & Sunindijo et al. (2014) \\
\hline BI4 & How likely is it that you are willing to pay premium price to hire the contractor? & Sunindijo et al. (2014) \\
\hline
\end{tabular}

the latent dimensions (along with the key associated attributes) further provide a theoretical basis to construct the research framework of the study depicted by Figure 1, where an arrow shows the direction of influence in the hypothesized structural model. Moreover, based on the above-mentioned theoretical framework, the following statements were hypothesized for this research:

$\mathrm{H} 1$ : Reliability has a positive influence on construction client satisfaction;
$\mathrm{H} 2$ : Responsiveness has a positive influence on construction client satisfaction;

H3: Assurance has a positive influence on construction client satisfaction;

$\mathrm{H} 4$ : Empathy has a positive influence on construction client satisfaction;

$\mathrm{H} 5$ : Tangibles have a positive influence on construction client satisfaction;

H6: Customer satisfaction has a positive influence on behaviour intention. 


\section{Research method}

To provide an empirical assessment of the proposed research model shown in Figure 1, this study adopts a quantitative technique using a cross-sectional data collection approach. Due to time limitations, reduction of cost, increased ease of distribution, improved data accuracy and difficulties in data collection, a questionnaire survey methodology was used as the main source of the primary data (Durdyev et al. 2017d; Taleb et al. 2017). To assure consistency with the aim of the study, the SERVQUAL service quality scale measures (Parasuraman et al. 1988) were used to design the questionnaire survey. Additionally, the measures for customer satisfaction and behavioural intention are adopted mainly from the relevant literature depicted by Table 1 .

The scale quantifies the difference between client's expectation (desired level) and recent performance (perceived level) based on 22 measures across five broad categories, namely reliability, responsiveness, assurance, empathy and tangibles. A service receives an excellent rating if recent performance is higher than expectation; it is satisfied if there is no difference; and dissatisfied if performance is not at the same level with expectation (Vesel, Zabkar 2009).

Measuring service quality by means of the SERVQUAL has received broad attention from various service sectors. While Padma et al. (2010) measured service quality (SQ) in the health care sector, Cameran et al. (2010), Kettinger et al. (2009), Jani and Han (2008) and Ban et al. (2016) quantified SQ of professional services, information systems and the tourism sector, respectively. Furthermore, Trivellas and Dargenidou (2009) measured the SQ of the education sector, Amin and Isa (2008) of banking services, and Vesel and Zabkar (2009) of the retail sector. However, several studies have criticized the scale (Caro, Garcia 2007; Das et al. 2010; Ihtiyar, Ahmad 2012) and further modification and customization have been suggested, such as specifying the industry-specific features, in particular. In an early study from the clients' perspective, Wall and Payne (1973) criticised the scale due the apparent difference between client's expectation and service performance. Babakus and Boller (1992) found that the SQ score relies more on perception compared to expectation. Further, Brandon-Jones and Silvestro (2010) stressed the influence of confusion and apathy on the data quality due to the realisation of expectation and perception measures of the scale.

Notwithstanding the criticisms of the scale, there is a sufficient amount of studies suggesting that the SERVQUAL should be the basis for measuring service quality. Thus, this study aims to test whether the proposed model can conceptualise and explain the endogenous and exogenous variables using the SERVQUAL service quality measures adopted from the relevant literature on the subject, but with some modification to specify industryspecific features (refer to Table 1).
A convenience sample of experts (three construction clients and two consultants with relevant experience in client management) agreed to devote their time to participate in in-depth, face-to-face interviews, in order to validate the relevance of the items in the questionnaire, which were mainly sourced from Ahmed and Kangari (1995), Kang and James (2004) and Sunindijo et al. (2014). Thus, an open-ended questionnaire was designed to collect quantitative data as a part of the second stage of the paper. The questionnaire comprised two sections, where the first part investigates the demographic background of the respondents and the second part allows for further quantification of the relationships among service quality, client satisfaction and behavioural intention, which will eventually help to develop a structural equation model (second objective of the study). It is obvious that commercial projects will invest more resources and effort into achieving as high a service quality level as possible, which it is hypothesized will affect the client's behavioural intention, while the significant criteria for contractor qualification for public projects, due to limited budgets, is a project cost. Therefore, clients or client representatives of private projects in Cambodia were selected as potential respondents for this study. Construction clients of small and medium size projects in Phnom Penh were the targeted population as they form the vast majority of construction projects in Cambodia.

Structural equation modelling (SEM). Following the data collection stage, selecting an appropriate statistical analysis technique remains a challenge (Sarstedt et al. 2014). In this regard, this study utilises a Structural Equation Model (SEM) to quantify the relationships between service quality, construction client satisfaction, and their behavioural intentions in the Cambodian construction industry.

SEM is an appropriate and flexible technique to simultaneously assess constructs of the model and the hypothesised structural relations among variables via a measurement model and structural model analysis (Hair et al. 2013; Zhang et al. 2017). SEM method has been used in various studies around the world in several different industries like tourism and the hospitality industry service and manufacturing industries, transportation industry, construction industry, firms, universities and other industries and sectors (Mardani et al. 2017). However, due to the principal statistical assumptions and nature of fit statistics, there are two SEM approaches, namely the componentbased approach (i.e. partial least square) and the co-variance-based approach (CB-SEM) (Hair et al. 2013). While CB-SEM reduces the differences between the sample covariance and the predicted model by maximum likelihood function (Urbach, Ahlemann 2010), partial least square (PLS-SEM) maximises the co-variance score between dependent and predictor latent variables (Hair et al. 2013). Moreover, PLS-SEM provides estimation on single and multi-component models and canonical correlation (Hair et al. 2013). Instead of using the maximum likeli- 
hood (ML) estimation procedure, PLS-SEM is a regression analysis technique based on ordinary least squares (OLS), which aims to maximise the $\mathrm{R} 2$ values of the endogenous constructs (Hair et al. 2013).

Many studies recommend the utilisation of PLS-SEM (Henseler et al. 2009; Soto-Acosta et al. 2016) despite its drawback, particularly the procedure for examination of data (Rouse, Corbitt 2008). For instance, Wong (2013) claims that the PLS-SEM is the more proper tool for distribution of data and sample size, which compared to the CBSEM does not require a large sample size and normal distribution. PLS-SEM can also be utilised for the model that comprises both reflective and formative constructs simultaneously (Hair et al. 2013). On the other hand, CB-SEM is extremely sensitive to data normality, inter-dependence of observation, large sample size, and uniformity of variable metrics (Sosik et al. 2009). Problematic explanation of co-variance of all indicators is another reason for CB-SEM being an inappropriate technique for formative constructs (Henseler et al. 2009). Thus, this study applies PLS-SEM to construct the relationships between latent variables via SmartPLS software 3.0, which provides substantive statements about the relationship among latent variables.

\section{Results}

\subsection{Data demographics}

Following the pilot study, the main study proceeded with the actual data collection. The questionnaires were administered to construction clients or client representatives of private projects in Cambodia. Domestic construction clients of small and medium size projects in Phnom Penh were the targeted population as it is home to the majority of construction projects in the country. The data collection period for the study was between February and June 2017. Of 300 distributed questionnaires, 227 valid questionnaires were received by the cut-off date, which represents a response rate of about $77 \%$, with the rest of the survey responses being invalid or missing. While the sample size for the SEM methodology should be sufficiently large, there is a deficiency in the extant literature, which has a lack of clear consensus on required sample size. Thus, the response rate for this research satisfied the sample size requirements suggested by Doloi et al. (2011).

\subsection{Data analysis}

\subsubsection{Missing value treatment}

Missing values are a common problem in questionnaire survey based studies, which leads to difficulties in the multivariate data analyses in behavioural and social sciences (Rezaei 2015). Missing data of up to 5\% is within the accepted margins, and hence does not cause problematic results (Hair et al. 2013). Gold and Bentler (2000) recommend use of the Expectation Maximisation Method (EMM) to manage any missing values. Thus, the second phase of the data analysis was to adjust the missing values.
EMM generated Little's MCAR test statistics via SPSS 21.0, and according to test assumptions, the result should produce an insignificant Chi-Square result for randomization of missing values. The test result indicated that the data presented insignificant values, and values for the model were Chi-Square $=9171.382, \mathrm{DF}=1378$, Sig. $=0.784$.

\subsubsection{Common method bias}

Common method bias (CMB) influences the validity of the findings due to the item reliabilities, structural relationships and the co-variation between latent variables, which makes it crucial in quantitative studies (MacKenzie, Podsakoff 2012). Thus, the study applied Harman's onefactor test to determine whether the data includes any potential CMB (Hashim 2012). Statistical results suggest that common method biases are not a concern in this study, as CMB were found to be lower than $40 \%$ as recommended (Hashim 2012).

\subsubsection{Non-response bias}

Finally, to ensure that non-response bias is not a concern for the study, or in other words, the model constructs were the same in both early and late stages of administration, demographic indicators and responses were collected individually (Hair et al. 2013). It is widely accepted that non-response bias influences the generalizability of the research findings, and therefore are considered crucial during the data collection phase of questionnaire survey methods (Hair et al. 2013). Thus, based on the criterion p-value for the t-statistics greater than 0.05 - there were no early and late response conflicts (Hair et al. 2013).

\subsection{The measurement model}

Prior to structural equation modelling, it is important to examine relationship between the latent variables and their items. The measurement model of the study was further assessed based on the composite reliability, outer loadings, Cronbach's alpha, average variance extracted (AVE) and discriminant validity (Wong 2013). As presented in Table 2, the majority of the outer loadings are above the minimum (satisfactory) threshold value of 0.70 (Wong 2013). Composite and internal (Cronbach's $\alpha$ ) reliabilities are also above the minimum of 0.70 , therefore the measures are robust in terms of their internal consistency reliability (Wong 2013). The AVE values for each construct exceeded 0.50 , which demonstrates statistical significance of all items of the measurement model, and is consistent with the guidelines of Fornell and Larcker (1981).

In addition, Fornell-Larcker criteria were used (Ihtiyar 2018) to assess discriminant validity, which indicates the extent to which a given construct differs from other constructs (Roldan, Sanchez-Franco 2012). The discriminant validity results of all constructs are presented in Table 3, where the square roots of the AVEs of each construct are greater than their correlations with any other construct, hence supporting the discriminant validity of the constructs (Al-Gahtani et al. 2007). 
Table 2. Measurement model assessment

\begin{tabular}{|l|c|c|c|c|c|}
\hline Items & Loadings & C.Alpha & rho_A & CR & AVE \\
\hline BI3 & 0.827 & 0.807 & 0.911 & 0.875 & 0.699 \\
BI1 & 0.883 & & & & \\
BI2 & 0.797 & & & & \\
\hline CS1 & 0.839 & 0.847 & 0.855 & 0.907 & 0.766 \\
CS2 & 0.881 & & & & \\
CS3 & 0.904 & & & & \\
\hline ASU1 & 0.832 & 0.897 & 0.903 & 0.920 & 0.658 \\
ASU2 & 0.782 & & & & \\
ASU3 & 0.797 & & & & \\
ASU4 & 0.826 & & & & \\
ASU5 & 0.842 & & & & \\
\hline RLB1 & 0.787 & 0.853 & 0.861 & 0.895 & 0.631 \\
RLB 2 & 0.820 & & & & \\
RLB 3 & 0.803 & & & & \\
RLB 4 & 0.839 & & & & \\
RLB 5 & 0.718 & & & & \\
\hline EMP1 & 0.801 & 0.743 & 0.758 & 0.838 & 0.566 \\
EMP2 & 0.696 & & & & \\
EMP3 & 0.829 & & & & \\
EMP4 & 0.669 & & & & \\
\hline RES1 & 0.933 & 0.912 & 0.928 & 0.944 & 0.850 \\
RES2 & 0.911 & & & & \\
RES3 & 0.922 & & & & \\
\hline TNG1 & 0.856 & 0.883 & 0.896 & 0.915 & 0.685 \\
TNG2 & 0.893 & & & & \\
TNG3 & 0.890 & & & & \\
TNG4 & 0.796 & & & & \\
\hline
\end{tabular}

\subsection{The structural model}

Once a satisfactory assessment of the measurement model has been achieved, it is possible to further evaluate the structural model. PLS-SEM mainly focuses on prediction, and its aim is to maximise the variance of the dependent variables. Thus, the first step of a PLS model evaluation should be on the basis of the coefficient of determination (R2), which indicates the amount of variance, and is a measure of the predictive power of the construct in question (Chin 2010). To achieve a required level of explanatory power, Chin (1998) classified the R2 values as substantial, moderate, and weak for $0.67,0.33$ and 0.19 , respectively. Thus, the model explains $41.2 \%$ of the variance in client satisfaction and $33 \%$ of the variance in behavioural intention, which indicates a moderate level of explanatory power (refer to Figure 2).

\section{Discussion and conclusions}

Several authors have emphasized the multi-dimensional nature of service quality and its influence on construction client satisfaction (Kang, James 2004; Yang, Peng 2008; Kärnä et al. 2009; Li et al. 2013; Aliakbarlou et al. 2017; Hadidi et al. 2017; Ihtiyar 2017). However, a review of the relevant literature suggests that the findings in other countries' context may not be applicable in Cambodia, which is obviously due to the difference in the perception of service quality among construction clients in the country. Therefore, this study sought to verify the Cambodian perspective that conceptualizes client satisfaction in relation to dimensions of service quality (refer to Table 1). This study reveals several interesting outcomes. Firstly, this study tested and confirmed the positive influence of service quality dimensions on construction client satisfaction. A second finding of this study is the confirmation of the significant influence of client satisfaction on behavioural intention from the Cambodian construction clients' perspective. Further, Table 4 presents the hypotheses of this research and conclusions, where the 'conclusion' column explains whether that hypothesis was supported.

Furthermore, SmartPLS-based results show that all path coefficients are positive (i.e. in the hypothesized direction) and statistically significant at $\mathrm{p}<0.01$. The structural model results show a positive relationship between all constructs of service quality and client satisfaction.

First dimension of service quality is reliability, which refers to whether the project procured at the promised time, has a positive but weak ( $\beta=0.227)$ effect on CS, which is in contrast to past findings by Sunindijo et al. (2014). The second dimension is assurance has also the similar influence $(\beta=0.227)$ on CS, which concerns the

Table 3. Fornell-Larcker criteria (adopted from Al-Gahtani et al. 2007)

\begin{tabular}{|l|l|l|l|l|l|l|l|}
\hline Constructs & \multicolumn{1}{|c|}{ BI } & \multicolumn{1}{c|}{ CS } & ASU & RE & EMP & RS & TNG \\
\hline BI & $\mathbf{0 . 6 9 9}$ & & & & & & \\
CS & 0.055 & $\mathbf{0 . 7 6 6}$ & & & & & \\
ASU & 0.003 & 0.516 & $\mathbf{0 . 6 5 8}$ & & & & \\
RLB & 0.002 & 0.529 & 0.464 & $\mathbf{0 . 6 3 1}$ & & & \\
EMP & 0.013 & 0.430 & 0.670 & 0.384 & $\mathbf{0 . 5 6 6}$ & & \\
RES & 0.066 & 0.514 & 0.462 & 0.628 & 0.388 & $\mathbf{0 . 8 5 0}$ & \\
TNG & 0.022 & 0.531 & 0.533 & 0.595 & 0.508 & 0.237 & $\mathbf{0 . 6 8 5}$ \\
\hline
\end{tabular}




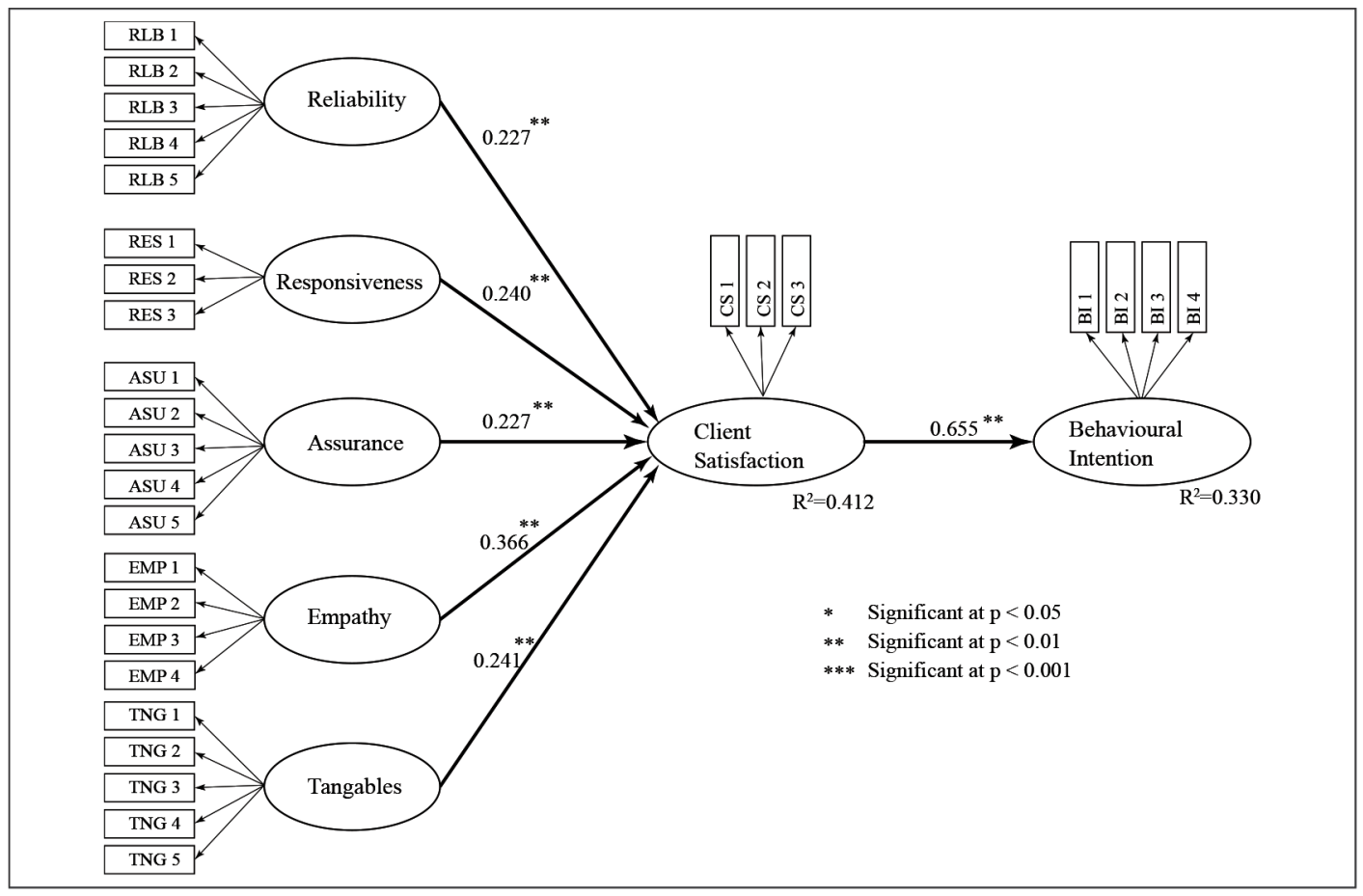

Figure 2. The structural equation model

contractor's quality standard, knowledge to answer the questions posed by client, and the most significant one is whether contractor provides all these services in courtesy. The result corroborates with the findings of Fischgrund and Omachonu (2014). Responsiveness, which is the third

Table 4. Hypotheses conclusions of the research

\begin{tabular}{|c|c|c|}
\hline Hypothesis & Finding & Conclusion \\
\hline $\begin{array}{l}\text { H1: Reliability has a } \\
\text { positive influence on } \\
\text { construction client } \\
\text { satisfaction }\end{array}$ & $\begin{array}{l}\text { Yes } \\
(\beta=0.227, p<0.01)\end{array}$ & Supported \\
\hline $\begin{array}{l}\mathrm{H} 2 \text { : Responsiveness } \\
\text { has a positive } \\
\text { influence on } \\
\text { construction client } \\
\text { satisfaction }\end{array}$ & $\begin{array}{l}\text { Yes } \\
(\beta=0.240, p<0.01)\end{array}$ & Supported \\
\hline $\begin{array}{l}\text { H3: Assurance has a } \\
\text { positive influence on } \\
\text { construction client } \\
\text { satisfaction }\end{array}$ & $\begin{array}{l}\text { Yes } \\
(\beta=0.227, p<0.01)\end{array}$ & Supported \\
\hline $\begin{array}{l}\text { H4: Empathy has a } \\
\text { positive influence on } \\
\text { construction client } \\
\text { satisfaction }\end{array}$ & $\begin{array}{l}\text { Yes } \\
(\beta=0.366, p<0.01)\end{array}$ & Supported \\
\hline $\begin{array}{l}\text { H5: Tangibles has a } \\
\text { positive influence on } \\
\text { construction client } \\
\text { satisfaction }\end{array}$ & $\begin{array}{l}\text { Yes } \\
(\beta=0.241, p<0.01)\end{array}$ & Supported \\
\hline $\begin{array}{l}\text { H6: Customer } \\
\text { satisfaction has a } \\
\text { positive influence on } \\
\text { behaviour intention }\end{array}$ & $\begin{array}{l}\text { Yes } \\
(\beta=0.655, p<0.01)\end{array}$ & Supported \\
\hline
\end{tabular}

dimension, is characterized by the willingness to help clients, provision of immediate service and keeping the client updated on the performed service, and has a positive but weak to be significant $(\beta=0.240)$. This confirms Kang and James (2004) result in which they found that the responsive contractor will continuously update the client who would eventually make a positive contribution. While tangibles has a similar positive but weak influence $(\beta=0.241)$ to be significant on CS, which is concerned with the resourcefulness of the contractor, empathy, which is characterised by has the highest significance ( $\beta=0.366)$ among the constructs of service quality. Above all, the model reveals a strong and positive relationship between the construct CS and behavioural intention $(\beta=0.655)$, which aligns with the research findings of Kang and James (2004) and Sunindijo et al. (2014).

Considering the positive and influence of the service quality constructs on client satisfaction, construction companies should pay more attention to: 1) responsiveness by providing just on time information (RES1), and service (RES2) (Sunindijo et al. 2014); 2) reliability by delivering a project as promised (RLB1) (Lloyd-Walker, Walker 2011) along with a continuous work progress report (RLB5) (Karna 2004) and helpful approach towards solving clients' problems (Fischgrund, Omachonu 2014). Moreover, assuring the client with the highest quality of project work (ASU2) (Gunning 2000) and displaying consistent courteous (ASU3) (Kale, Arditi 2002) were significant, which is particularly relevant in the Cambodian cultural context.

Implications for research and industry. In the context of the global construction industry, the research outcomes have enriched knowledge about the relationship between service quality, client satisfaction, and behavioural 
intention in a typical developing country setting. In the context of the construction industry of Cambodia, the contribution of this study to fill a significant knowledge gap cannot be disregarded, as it quantifies the relationship between the constructs. It is hoped that the confirmation of the theoretical model of the study provides guidance for players at the forefront of the industry to understand how construction clients assess the quality level of services, and how contractors meet their needs. The general perception of the quality of services among construction clients in Cambodia is towards the main objectives of a typical construction project, which are time, cost and quality. In other words, as long as a construction project is completed within the planned time and cost, and complies with quality requirements, the client satisfaction level is perceived to be at the highest level. Even though this attitude is consistent with findings of Forsythe (2016), increasing levels of foreign investment in the construction industry (residential projects in particular) increases the level of competitiveness, which therefore forces local companies to focus their efforts towards an increase in the service quality they provide, and ultimately in their ability to procure future new projects.

Limitations of this study. First, the findings of this study were influenced by the feedback from the construction clients of small and medium projects in Cambodia. However, future research can be conducted to include the representatives of large construction projects delivered in the country. Second, the questionnaire survey used in this study was administered to construction clients in the Khmer language. The meanings of some of the statements are assumed to be unintentionally altered during the translation from English to the local language. Lack of input from other construction stakeholders, who are responsible for the quality of the construction service provided, is another significant limitation of this study.

Although the outcomes of this study were a short scoping exercise, they form a significant base for the relationship between service quality, client satisfaction and behavioural intention in the Cambodian construction context. The scope of the findings is hoped to be sufficient to draw a picture of the relationship between the constructs, and report that service quality has a significant influence on client satisfaction, and therefore on the future behaviour intention of the client. Therefore, the significance of the items under the clusters is strong enough to motivate industry stakeholders to address the items and invest in improving them. Thus, service quality among construction companies (domestic companies in particular) in Cambodia can be significantly improved to enable efficient delivery of projects at the required level of quality and adjust their service strategies for the competitive construction environment. In addition, the findings are not future-proof; therefore, rapid changes in the construction industry of Cambodia would necessitate re-investigation of service quality items and re-quantification of the influence of service quality on client satisfaction.

\section{Acknowledgements}

The support of the Department of Engineering and Architectural Studies, Ara Institute of Canterbury and the Research office of Zaman University are acknowledged. Appreciation is given to the construction clients and their representatives in Cambodia for providing their opinions, support and assistance.

\section{References}

Abdullah, M. A.; Manaf, N. H. A.; Yusuf, M. B. O.; Ahsan, K.; Azam, S. M. F. 2014. Determinants of customer satisfaction on retails banks in New Zealand: An empirical analysis using structural equation modeling, Global Economy and Finance Journal 7(1): 63-82.

https://doi.org/10.21102/geff.2014.03.71.04

Ahmed, S. M.; Kangari, R. 1995. Analysis of client-satisfaction factors in construction industry, Journal of Construction Engineering and Management 11(2): 36-44.

https://doi.org/10.1061/(ASCE)0742-597X(1995)11:2(36)

Al-Gahtani, S. S.; Hubona, G. S.; Wang, J. 2007. Information technology (IT) in Saudi Arabia: Culture and the acceptance and use of IT, Information \& Management 44(8): 681-691. https://doi.org/10.1016/j.im.2007.09.002

Aliakbarlou, S.; Wilkinson, S.; Costello, S. B. 2017. Exploring construction client values and qualities: Are these two distinct concepts in construction studies?, Built Environment Project and Asset Management 7(3): 234-252.

https://doi.org/10.1108/BEPAM-06-2016-0023

Amin, M.; Isa, Z. 2008. An examination of the relationship between service quality perception and customer satisfaction: A SEM approach towards Malaysian Islamic banking, International Journal of Islamic and Middle Eastern Finance and Management 1(3): 191-209.

https://doi.org/10.1108/17538390810901131

Arslan, G.; Kivrak, S. 2009. Critical factors to company success in the construction industry, International Journal of Human and Social Sciences 4(8): 561-564.

Babakus, E.; Boller, G. W. 1992. An empirical assessment of the SERVQUAL scale, Journal of Business Research 24(3): 25368. https://doi.org/10.1016/0148-2963(92)90022-4

Ban, O.-I.; Tara, I. G.; Bogdan, V.; Tuşe, D.; Bologa, S. G. 2016. Evaluation of hotel quality attribute importance through fuzzy correlation coefficient, Technological and Economic Development of Economy 22(4): 471-492. https://doi.org/10.3846/20294913.2016.1144657

Barrett, P. 2000. Systems and relationships for construction quality, International Journal of Quality \& Reliability Management 17(4/5): 377-392.

https://doi.org/10.1108/02656710010298409

Brandon-Jones, A.; Silvestro, R. 2010. Measuring internal service quality: Comparing the gap-based and perceptions-only approaches, International Journal of Operations and Production Management 30(12): 1291-1318. https://doi.org/10.1108/01443571011094271

Byrne, B. M. 2009. Structural equation modeling with AMOS: Basic concepts, applications and programming. $2^{\text {nd }}$ ed. London: Routledge.

Cameran, M.; Moizer, P.; Pettinicchio, A. 2010. Customer satisfaction, corporate image, and service quality in professional services, The Service Industries Journal 30(3): 421-435. https://doi.org/10.1080/02642060802236111 
Caro, L. M.; Garcia, J. A. M. 2007. Measuring perceived service quality in urgent transport service, Journal of Retailing and Consumer Services 14(1): 60-72.

https://doi.org/10.1016/j.jretconser.2006.04.001

Chin, W. W. 1998. The partial least squares approach to structural equation modelling, Modern Methods for Business Research 295(2): 295-336.

Chin, W. W. 2010. How to write up and report PLS analysis, in Handbook of partial least squares. Berlin, Heidelberg: Springer, 655-690.

Das, A.; Kumar, V.; Saha, G. C. 2010. Retail service quality in context of CIS countries, International Journal of Quality and Reliability Management 27(6): 658-683.

https://doi.org/10.1108/02656711011054542

Doloi, H.; Iyer, K. C.; Sawhney, A. 2011. Structural equation model for assessing impacts of contractor's performance on project success, International Journal of Project Management 29(6): 687-695.

https://doi.org/10.1016/j.ijproman.2010.05.007

Durdyev, S.; Ihtiyar, A.; Ismail, S.; Ahmad, F. S.; Abu Bakar, N. 2014. Productivity and service quality: Factors affecting in service industry, Procedia - Social and Behavioral Sciences 109: 487-491. https://doi.org/10.1016/j.sbspro.2013.12.494

Durdyev, S.; Ismail, S. 2016. On-site construction productivity in Malaysian infrastructure projects, Structural Survey 34(4/5): 446-462. https://doi.org/10.1108/SS-12-2015-0058

Durdyev, S.; Ismail, S.; Bakar, N. A. 2013. Construction productivity in Turkmenistan: Survey of the constraining factors, International Journal of e-Education, e-Business, e-Management and e-Learning 3(1): 18-23.

Durdyev, S.; Ismail, S.; Kandymov, N. 2017c. Structural equation model of the factors affecting construction labor productivity, Journal of Construction Engineering and Management (in Print).

Durdyev, S.; Mbachu, J. 2011. On-site labour productivity of New Zealand construction industry: Key constraints and improvement measures, Construction Economics and Building 11(3): 18-33. https://doi.org/10.5130/ajceb.v11i3.2120

Durdyev, S.; Mbachu, J. 2017. Key constraints to labour productivity in residential building projects: Evidence from Cambodia, International Journal of Construction Management (in Print). https://doi.org/10.1080/15623599.2017.1326301

Durdyev, S.; Omarov, M.; Ismail, S. 2017a. Causes of delay in residential construction projects in Cambodia, Cogent Engineering 4(1): 1-12.

https://doi.org/10.1080/23311916.2017.1291117

Durdyev, S.; Omarov, M.; Ismail, S.; Lim, M. 2017b. Significant contributors to cost overruns in construction projects of Cambodia, Cogent Engineering 4(1): 1-10.

https://doi.org/10.1080/23311916.2017.1383638

Durdyev, S.; Sherif, M.; Lay, M. L.; Ismail, S. 2017d. Key factors affecting construction safety performance in developing countries: Evidence from Cambodia, Construction Economics and Building 17(4): 48-65.

https://doi.org/10.5130/AJCEB.v17i4.5596

Eager, D.; Vernon, M.; Zahorjan, J. 2001. Minimizing bandwidth requirements for on-demand data delivery, IEEE Transactions on Knowledge and Data Engineering 13(5): 742-757. https://doi.org/10.1109/69.956098

Fajgelbaum, P.; Grossman, G. M.; Helpman, E. 2011. Income distribution, product quality, and international trade, Journal of Political Economy 119(4): 721-765. https://doi.org/10.1086/662628
Ferreira, F. A. F.; Spahr, R. W.; Sunderman, M. A.; Banaitis, A.; Ferreira, J. J. M. 2017. A learning-oriented decision-making process for real estate brokerage service evaluation, Service Business 11(3): 453-474.

https://doi.org/10.1007/s11628-016-0315-4

Fischgrund, J.; Omachonu, V. 2014. Quality in construction: Identifying the gaps, International Journal of Construction Engineering and Management 3(2): 65-73. https://doi.org/10.5923/j.ijcem.20140302.04

Fornell, C.; Larcker, D. F. 1981. Evaluating structural equation models with unobservable variables and measurement error, Journal of Marketing Research 18(1): 39-50. https://doi.org/10.2307/3151312

Forsythe, P. 2015. Monitoring customer perceived service quality and satisfaction during the construction process, Construction Economics and Building 15(1): 19-42. https://doi.org/10.5130/ajceb.v15i1.4172

Forsythe, P. J. 2016. Construction service quality and satisfaction for a targeted housing customer, Engineering, Construction and Architectural Management 23(3): 323-348. https://doi.org/10.1108/ECAM-05-2015-0076

Foster, S. T.; Ganguly, K. K. 2013. Managing quality: Integrating the supply chain. $5^{\text {th }}$ ed. Harlow, Essex: Pearson Education Limited.

Gold, M. S.; Bentler, P. M. 2000. Treatments of missing data: A Monte Carlo comparison of RBHDI, iterative stochastic regression imputation, and expectation-maximization, Structural Equation Modeling 7(3): 319-355. https://doi.org/10.1207/S15328007SEM0703_1

Gunning, J. G. 2000. Models of customer satisfaction and service quality as research instruments in construction management, in Proceedings of the 16th Annual Association of Researchers in Construction Management Conference, 6-8 September 2000, Glasgow Caledonian University, 21-30.

Hadidi, L.; Assaf, S.; Aluwfi, K.; Akrawi, H. 2017. The effect of ISO 9001 implementation on the customer satisfaction of the engineering design services, International Journal of Building Pathology and Adaptation 35(2): 176-190. https://doi.org/10.1108/IJBPA-01-2017-0004

Hair, Jr. J. F.; Hult, G. T. M.; Ringle, C.; Sarstedt, M. 2013. A primer on partial least squares structural equation modeling (PLS-SEM). SAGE Publications, Inc.

Hashim, K. F. 2012. Understanding the determinants of continuous knowledge sharing intention within business online communities: PhD thesis. Auckland University of Technology.

Henseler, J.; Ringle, C. M.; Sinkovics, R. R. 2009. The use of partial least squares path modeling in international marketing, Advances in International Marketing 20: 277-319. https://doi.org/10.1108/S1474-7979(2009)0000020014

Hsu, Y. H.; Juan, Y. K. 2016. ANN-based decision model for the reuse of vacant buildings in urban areas, International Journal of Strategic Property Management 20(1): 31-43. https://doi.org/10.3846/1648715X.2015.1101626

Ihtiyar, A. 2017. A conceptual framework to explain transition of intercultural communication conflict, social environment and personality, Journal of Management, Economics, and Industrial Organization 1(1): 37-50.

Ihtiyar, A. 2018. The role of social environment and personality: validation of antecedents of intercultural communication competence and its effects on customer satisfaction, Journal of Management, Economics, and Industrial Organization 2(1): 33-59. 
Ihtiyar, A.; Ahmad, F. S. 2012. Measurement of perceived service quality in the food retail industry of Turkey, International Business Management 6(2): 249-255.

https://doi.org/10.3923/ibm.2012.249.255

Ihtiyar, A.; Ahmad, F. S. 2014. Intercultural communication competence as a key activator of purchase intention, Procedia - Social and Behavioral Sciences 150: 590-599. https://doi.org/10.1016/j.sbspro.2014.09.078

Jani, D.; Han, H. 2008. Investigating the key factors affecting behavioral intentions: Evidence from a full-service restaurant setting, International Journal of Contemporary Hospitality Management 23(7): 1000-1018.

https://doi.org/10.1108/09596111111167579

Kale, S.; Arditi, D. 2002. Competitive positioning in United States construction industry, Journal of Construction Engineering and Management 128(3): 238-247. https://doi.org/10.1061/(ASCE)0733-9364(2002)128:3(238)

Kang, G.; James, J. 2004. Service quality dimensions: An examination of Grönroos's service quality model, Managing Service Quality: An International Journal 14(4): 266-277.

Karna, S. 2004. Analysing customer satisfaction and quality in construction - the case of public and private customers, Nordic Journal of Surveying and Real Estate Research 2: 67-80.

Kärnä, S.; Junnonen, J.; Sorvala, V. 2009. Modelling structure of customer satisfaction with construction, Journal of Facilities Management 7(2): 111-127.

https://doi.org/10.1108/14725960910952505

Kettinger, W. J.; Park, S. H.; Smith, J. 2009. Understanding the consequences of information systems service quality on IS service reuse, Information \& Management 46(6): 335-341. https://doi.org/10.1016/j.im.2009.03.004

Kotler, P.; Armstrong, G. 2013. Principles of marketing. $15^{\text {th }}$ Global Edition. Pearson.

Lee, S. K.; Yu, J. H. 2012. Success model of project management information system in construction, Automation in Construction 25: 82-93. https://doi.org/10.1016/j.autcon.2012.04.015

Lessing, B.; Thurnell, D.; Durdyev, S. 2017. Main factors causing delays in large construction projects: Evidence from New Zealand, Journal of Management, Economics, and Industrial Organization 1(2): 63-82.

Li, T. H. Y.; Ng, S. T.; Skitmore, M. 2013. Evaluating stakeholder satisfaction during public participation in major infrastructure and construction projects: A fuzzy approach, Automation in Construction 29: 123-135.

https://doi.org/10.1016/j.autcon.2012.09.007

Lloyd-Walker, B.; Walker, D. 2011. Authentic leadership for 21st century project delivery, International Journal of Project Management 29(4): 383-395.

https://doi.org/10.1016/j.ijproman.2011.02.004

MacKenzie, S. B.; Podsakoff, P. M. 2012. Common method bias in marketing: Causes, mechanisms, and procedural remedies, Journal of Retailing 88(4): 542-555.

https://doi.org/10.1016/j.jretai.2012.08.001

Maloney, W. F. 2002. Construction product/service and customer satisfaction, Journal of Construction Engineering and Management 128(6): 522-529. https://doi.org/10.1061/(ASCE)0733-9364(2002)128:6(522)

Mardani, A.; Streimikiene, D.; Zavadskas, E. K.; Cavallaro, F.; Nilashi, M.; Jusoh, A.; Zare, H. 2017. Application of structural equation modeling (SEM) to solve environmental sustainability problems: A comprehensive review and meta-analysis, Sustainability 9: 1814. https://doi.org/10.3390/su9101814

Ministry of Economy and Finance (MEF). 2016. Cambodia macroeconomic monitor mid-year assessment 2016 [online], [cited 15 March 2017]. Available from Internet: http://www.mef.gov.kh/documents/shares/CMM_Mid2016-Assessment-English-Version.pdf

Nadiri, H.; Gunay, G. N. 2013. An empirical study to diagnose the outcomes of customers' experiences in trendy coffee shops, Journal of Business Economics and Management 14(1): 22-53. https://doi.org/10.3846/16111699.2011.631742

Oliver, R.; Linda, G. 1981. Effect of satisfaction and its antecedents on consumer preference and intention, Advances in Consumer Research 8: 88-93.

Osei-Kyei, R.; Chan, A. P. C.; Javed, A. A.; Ameyaw, E. E. 2017. Critical success criteria for public-private partnership projects: international experts' opinion, International Journal of Strategic Property Management 21(1): 87-100. https://doi.org/10.3846/1648715X.2016.1246388

Othman, A. 2015. An international index for customer satisfaction in the construction industry, International Journal of Construction Management 15(1): 33-58.

https://doi.org/10.1080/15623599.2015.1012140

Padma, P.; Rajendran, C.; Lokachari, P. S. 2010. Service quality and its impact on customer satisfaction in Indian hospitals: Perspectives of patients and their attendants, Benchmarking: An International Journal 17(6): 807-841. https://doi.org/10.1108/14635771011089746

Parasuraman, A.; Zeithaml, V. A.; Berry, L. L. 1988. SERVQUAL: A multiple-item scale for measuring consumer perceptions of service quality, Journal of Retailing 64(1): 12-40.

Preece, C.; Tarawneh, S. 1997. Service quality for client satisfaction on design \& build projects, in Proceedings of the $13^{\text {th }}$ Annual Association of Researchers in Construction Management Conference, 15-17 September 1997, King's College, Cambridge, 264-274.

Rezaei, S. 2015. Segmenting consumer decision-making styles (CDMS) toward marketing practice: A partial least squares (PLS) path modeling approach, Journal of Retailing and Consumer Services 22: 1-15.

https://doi.org/10.1016/j.jretconser.2014.09.001

Roldan, J. L.; Sanchez-Franco, M. J. 2012. Variance based structural equation modelling: Guidelines for using partial least squares in information systems research, Chapter 10, in Research methodologies, innovations and philosophies in software systems engineering and information systems. IGI Global, 193-221.

Rouse, A.; Corbitt, B. 2008. There's SEM and "SEM": A critique of the use of PLS regression in information systems research, in Proceedings of the $19^{\text {th }}$ Australasian Conference on Information Systems, 3-5 December 2008, Christchurch, New Zealand, 845-855.

Sarstedt, M.; Ringle, C. M.; Henseler, J.; Hair, J. F. 2014. On the emancipation of PLS-SEM: A commentary on Rigdon (2012), Long Range Planning 47(3): 154-160. https://doi.org/10.1016/j.lrp.2014.02.007

Sheth, J. N.; Sethia, N. K.; Srinivas, S. 2011. Mindful consumption: A customer-centric approach to sustainability, Journal of the Academy of Marketing Science 39(1): 21-39. https://doi.org/10.1007/s11747-010-0216-3

Sosik, J. J.; Kahai, S. S.; Piovoso, M. J. 2009. Silver bullet or voodoo statistics? A primer for using the partial least squares data analytic technique in group and organization research, Group \& Organization Management 34(1): 5-36. https://doi.org/10.1177/1059601108329198

Soto-Acosta, P.; Popa, S.; Palacios-Marqués, D. 2016. E-business, organizational innovation and firm performance in manufacturing SMEs: an empirical study in Spain, Technological and 
Economic Development of Economy 22(6): 885-904. https://doi.org/10.3846/20294913.2015.1074126

Sunindijo, R. Y.; Hadikusumo, B. H.; Phangchunun, T. 2014. Modelling service quality in the construction industry, International Journal of Business Performance Management 15(3): 262-276. https://doi.org/10.1504/IJBPM.2014.063026

Taleb, H.; Ismail, S.; Wahab, M. H.; Mardiah, W. N.; Rani, W. M.; Amat, R. C. 2017. An overview of project communication management in construction industry projects, Journal of Management, Economics, and Industrial Organization 1(1): 1-9.

Torbica, Z. M.; Stroh, R. C. 2001. Customer satisfaction in home building, Journal of Construction Engineering and Management 127(1): 82-86.

https://doi.org/10.1061/(ASCE)0733-9364(2001)127:1(82)

Trivellas, P.; Dargenidou, D. 2009. Leadership and service quality in higher education: The case of the Technological Educational Institute of Larissa, International Journal of Quality and Service Sciences 1(3): 294-310. https://doi.org/10.1108/17566690911004221

Urbach, N.; Ahlemann, F. 2010. Structural equation modeling in information systems research using partial least squares, Journal of Information Technology Theory and Application 11(2): 5-40.

Vandermerwe, S. 1994. From tin soldiers to Russian dolls: creating added value through services. Oxford: Butterworth-Heinemann.

Vargo, S. L.; Lusch, R. F. 2004. Evolving to a new dominant logic for marketing, Journal of Marketing 68(1): 1-17. https://doi.org/10.1509/jmkg.68.1.1.24036

Vera, J.; Trujillo, A. 2013. Service quality dimensions and superior customer perceived value in retail banks: An empirical study on Mexican consumers, Journal of Retailing and Consumer Services 20(6): 579-586.

https://doi.org/10.1016/j.jretconser.2013.06.005

Vesel, P.; Zabkar, V. 2009. Managing customer loyalty through the mediating role of satisfaction in the DIY retail loyalty program, Journal of Retailing and Consumer Services 16(5): 396-406. https://doi.org/10.1016/j.jretconser.2009.05.002

Wall, T. D.; Payne, R. 1973. Are deficiency scores deficient?, Journal of Applied Psychology 58(3): 322-326. https://doi.org/10.1037/h0036227

Womack, J. P.; Jones, D. T.; Roos, D. 2008. The machine that changed the world. New York: Simon and Schuster.

Wong, K. K. K. 2013. Partial least squares structural equation modeling (PLS-SEM) techniques using SmartPLS, Marketing Bulletin 24(1): 1-32.

Wu, C. H.; Liang, R. 2009. Effect of experiential value on customer satisfaction with service encounters in luxury-hotel restaurants, International Journal of Hospitality Management 28(4): 586-593. https://doi.org/10.1016/j.ijhm.2009.03.008

Yang, J.; Peng, S. 2008. Development of a customer satisfaction evaluation model for construction project management, Building and Environment 43(4): 458-468. https://doi.org/10.1016/j.buildenv.2006.07.044

Yasamis, F; Arditi, D.; Mohammadi, J. 2002. Assessing contractor quality performance, Construction Management and Economics 20(3): 211-223. https://doi.org/10.1080/01446190110113693

Yonn, R. 2017. The effects of Cambodia economy on ASEAN economic moving forward, Journal of Management, Economics, and Industrial Organization 1(2): 1-16.
Zhang, L.; Chen, X.; Suo, Y. 2017. Interrelationships among critical factors of work flow reliability in lean construction, Journal of Civil Engineering and Management 23(5): 621-632. https://doi.org/10.3846/13923730.2016.1217921

Zulu, S.; Chileshe, N. 2010. Service quality of building maintenance contractors in Zambia: A pilot study, International Journal of Construction Management 10(3): 63-81. https://doi.org/10.1080/15623599.2010.10773150 